\title{
STUDI ISOTERM DAN KINETIKA ADSORPSI COD (CHEMICAL OXYGEN DEMAND) PADA AIR SUNGAI TERHADAP KARBON AKTIF KAYU ULIN
}

\author{
ISOTERM AND KINETICS STUDY OF COD (CHEMICAL OXYGEN DEMAND) ADSORTION IN \\ RIVER WATER ON ULIN WOOD ACTIVE CARBON
}

\author{
Muhammad Aulia ${ }^{1}$, Mahmud ${ }^{1}$, Badaruddin Mu'min ${ }^{1}$ \\ ${ }^{1}$ Program Studi Teknik Lingkungan, Fakultas Teknik, Universitas Lambung Mangkurat Jl. Jend. \\ Ahmad Yani Km 36, Banjarbaru, Kalimantan Selatan, 70714, Indonesia \\ E-mail:1610815310010@mhs.ulm.ac.id
}

\begin{abstract}
Abstrak
Limbah kayu ulin di Kalimantan Selatan sangat banyak jumlahnya dan belum dimanfaatkan secara optimal. Kayu ulin berpotensi dimanfaatkan sebagai adsorben untuk menurunkan bahan organik. Kayu ulin dijadikan adsorben karena mempunyai sifat yang keras dengan material yang hanya mengandung karbon. Peningkatan luas permukaan adsorben arang kayu ulin dapat dilakukan melalui aktivasi kimia. Metode yang digunakan dalam penelitian ini yakni aktivasi secara fisika menggunakan furnace. Berdasarkan hasil penelitian gambaran proses adsorpsi yang tepat pada model Isoterm adsorpsi COD terhadap karbon aktif kayu ulin berturut-turut adalah model Isoterm Freundlich dengan nilai $\mathrm{R}^{2} 0,8898$; Langmuir dengan nilai $\mathrm{R}^{2} 0,9320$; Redlich-Peterson dengan nilai $\mathrm{R}^{2} 0,957$; dan Temkin dengan nilai $\mathrm{R}^{2} 0,8559$, sedangkan pada penggambaran proses adsorpsi yang tepat dari model kinetika adsorpsi COD air sungai terhadap karbon aktif kayu ulin adalah model kinetika Pseudo orde dua. Berdasarkan hasil dari model isoterm dan kinetika mekanisme adsorpsi COD air sungai terjadi secara fisika dan kimia dengan didominasi oleh mekanisme secara kimia.
\end{abstract}

Kata kunci: Adsorpsi, Air Sungai, COD, Karbon Aktif, Kayu Ulin

\begin{abstract}
Ironwood waste in South Kalimantan is very large and has not been used optimally. Ironwood has the potential to be used as an adsorbent to reduce organic matter. Ironwood is used as an adsorbent because it has hard properties with a material that only contains carbon, ironwood charcoal can also be increased in surface area and its absorption capacity through chemical activation. The method used in this research is physical activation using a furnace. Based on the results of the research, the appropriate isotherm model to describe the COD adsorption process on ironwood activated carbon sequentially is the Langmuir model: Redlich-Peterson: Freundlich: Temkin with a $R^{2}$ value of 0.9320: 0.8898: 0.957: 0.8559. The kinetics model that accurately describes the COD adsorption process of river water against ironwood activated carbon is a second order Pseudo kinetics model. Based on the results of the isotherm model and the kinetics of COD adsorption, river water occurs physically and chemically, dominated by chemical mechanisms.
\end{abstract}

Keywords: Adsorption, River Water, COD, Activated Carbon, Ironwood 


\section{PENDAHULUAN}

Kayu ulin merupakan kayu hutan yang khas dan banyak tumbuh di hutan Kalimantan. Kayu ulin berasal dari suku Dipterocarpaceae dan bernilai ekonomis yang tinggi. Pemanfaatan kayu ulin tidak hanya dilihat dari produk kayunya, tetapi juga produk non-kayu, ekologi, dan sosial budaya. Kayu ulin merupakan salah satu komoditas ekspor dari Kalimantan (Suharja \& Jumani, 2017). Kayu ulin dapat dimanfaatkan untuk bahan bangunan, perumahan, perlengkapan/atribut rumah tangga maupun sebagai bahan baku untuk beberapa jenis souvenir di daerah-daerah Indonesia bahkan sampai ke mancanegara (Badariah, 2013).

Mahdi,dkk (2018) menyebutkan bahwa sebesar 40,48\% limbah gergaji kayu dihasilkan oleh industri penggergajian kayu yang terdiri dari sabetan 22,32\% dan potongan kayu 9,39\%. Industri penggergajian di Kalimantan Selatan mempunyai produksi $71.777 .7592 \mathrm{~m}^{3}$. Penelitian ini menggunakan arang kayu ulin karena limbah kayu ulin cukup banyak jumlahnya di Kalimantan dan pemanfaatannya yang belum maksimal. Kayu ulin dapat digunakan sebagai adsorben untuk menurunkan bahan organik. Pemanfaatan kayu ulin menjadi adsorben memiliki potensi yang besar. Hal ini karena selain jumlahnya yang banyak khususnya di Kalimantan, juga karena memiliki sifat yang keras dengan material yang banyak mengandung karbon. Peningkatan daya serap arang aktif kayu ulin dapat ditingkatkan dengan memperbesar luas permukaan melalui aktivasi kimia (Matilda, 2016).

Adsorpsi merupakan proses penyerapan zat baik berupa molekul atau ion pada permukaan adsorben. Adsorpsi suatu zat yang terjadi padaxpermukaan adsorbenxdipengaruhi olehxbeberapa faktor, sehingga terdapat pola isoterm dan kinetika tertentu dan menjadi model proses adsorpsi. Studi isoterm dan kinetika berguna untuk industri yang melibatkan proses adsorpsi baik dalam pengolahan air minum, sintesis resin, dan lain-lain. Kapasitas adsorpsi dan tetapan kesetimbangan dapat ditentukan melalui model isoterm adsorpsi berupa model Langmuir, Freundlich, RedlichPeterson, dan Temkin. Pemodelan kinetika adsorpsi dapat dilakukan dengan menggunakan model Freundlich modifikasi, Pseudo orde satu, dan Pseudo orde dua.

Karbon aktif biasanya berasal dari sekam padi, jerami, kayu, serbuk kayu, limbah kayu gergaji, sabut kelapa, dan tempurung buah (Indis, 2013). Kayu ulin bisa dijadikan karbon aktif karena sifat yang dimiliki kayu tersebut dan cukup mudah ditemukan di Kalimantan (Matilda dkk., 2016). Adsorpsi merupakan proses perpindahan suatu zat baik berupa molekul maupun ion dari larutan ke dalam pori-pori adsorben (Sirajuddin dkk., 2017). Metode adsorpsi merupakan metode yang dapat direkomendasikan untuk penyerapan zat tertentu karena efektifitas, kemampuan daya serap, dan kapasitas adsorpsinya yang tinggi, serta pembiayaan operasionalnya yang rendah sehingga sangat menguntungkan (Syafalni dkk., 2012). Berdasarkan kajian tersebut limbah kayu ulin dapat dijadikan sebagai karbon aktif untuk proses adsorpsi.

\section{MATERIAL DAN METODE PENELITIAN}

\subsection{Material Penelitian}

Penelitian ini menggunakan beberapa material yaitu sampel air sungai, akuades, potongan kayu ulin sebanyak 1000 gr dengan ukuran $2 \mathrm{~cm} \times 1,5 \mathrm{~cm}$, larutan iodium $0,1 \mathrm{~N}$, natrium thiosulfate $\left(\mathrm{Na}_{2} \mathrm{~S}_{2} \mathrm{O}_{3}\right) 0,1 \mathrm{~N}$, larutan $\mathrm{NaOH} \quad 0,1 \mathrm{~N}$, larutan $\mathrm{HCl} 0,1 \mathrm{~N}$, larutan asam oksalat $0,01 \mathrm{~N}$, larutan $\mathrm{H}_{2} \mathrm{SO}_{4}$ $8 \mathrm{~N}$, larutan $\mathrm{KMnO}_{4} 0,1 \mathrm{~N}$ dan larutan $\mathrm{KMnO} 40,01 \mathrm{~N}$. 


\subsection{Pembuatan Adsorben Kayu Ulin}

Pembuatan adsorben dari limbah kayu ulin pada penelitian ini dibagi menjadi 2 tahapan, yakni: (1) preparasi limbah kayu ulin dengan memotong limbah kayu ulin dengan ukuran $2 \mathrm{~cm}$ x $1,5 \mathrm{~cm}$ kemudian dijemur selama 24 jam untuk selanjutnya dimasukkan kedalam tabung karbonasi serta dialirkan gas $\mathrm{N}_{2}$ selama 5 menit. Pada tahapan preparasi, tabung karbonasi yang bertekanan dimasukkan kedalam furnace untuk dilakukan proses pirolisis selama 2 jam dengan suhu $200^{\circ} \mathrm{C}$ dan proses pembakaran selama 4 jam dengan suhu $400^{\circ} \mathrm{C}$ agar terjadi penguraian senyawa organik penyusun kayu (Ridhuan dkk., 2018). Kemudian, karbon aktif yang sudah melalui tahap pirolisis dihancurkan hingga berukuran 80-100 mesh dan (2) proses aktivasi fisika yang dilakukan didalam furnace pada suhu $650^{\circ} \mathrm{C}$ selama 2 jam bertujuan untuk memperbesar pori-pori arang (Sembiring, 2003). Metode ini digunakan menggunakan gas nitrogen sebagai oksidator. Kemudian karbon aktif dikarakterisasi melalui uji kadar air, kadar abu dan daya serap iodium.

\subsection{Penentuan Kinerja Karbon Aktif Limbah Kayu Ulin}

Karakteristik karbon aktif limbah kayu ulin di uji melalui uji kadar air, kadar abu dan daya serap iodium. Persamaan yang digunakan dapat dilihat pada Persamaan 1 untuk uji kadar air, perhitungan kadar abu dapat dihitung dengan Persamaan $\mathbf{2}$ dan daya serap iodium dapat dihitung dengan Persamaan 3, yaitu:

$$
\text { Kadar air }(\%)=\frac{a-b}{a} \times 100 \%
$$

dengan keterangan a merupakan massa awal kabon aktif (gr), b merupakan massa akhir karbon aktif (gr) (Previanti, P., dkk, 2015).

$$
\text { Kadar abu }(\%)=\frac{b}{a} \times 100 \%
$$

a merupakan massa awal karbon aktif (gr), b merupakan massa akhir karbon aktif (gr) (Previanti, P., dkk, 2015).

$$
\text { Daya serap iod }(\mathrm{mg} / \mathrm{gram})=\frac{\left(V_{1}-V_{2}\right) \times N \times 126,5 \times 5}{a}
$$

$\mathrm{V}_{1}$ merupakan volume titrasi awal larutan $\mathrm{Na}_{2} \mathrm{~S}_{2} \mathrm{O}_{3}(\mathrm{ml}), \mathrm{V}_{2}$ merupakan volume titrasi akhir larutan $\mathrm{Na}_{2} \mathrm{~S}_{2} \mathrm{O}_{3}(\mathrm{ml}), \mathrm{N}$ merupakan normalitas $\mathrm{Na}_{2} \mathrm{~S}_{2} \mathrm{O}_{3}(\mathrm{~N})$, a merupakan massa awal karbon aktif (gr) (Yudhi, 2015).

\section{HASIL DAN PEMBAHASAN}

\subsection{Karakteristik Karbon Aktif Kayu Ulin}

Bahan baku kayu ulin yang digunakan pada penelitian ini berasal dari limbah pengolah jendela, pintu, dan lemari yang terdapat di Jl. Dahlina Raya, Kecamatan Banjarbaru Selatan, Kota Banjarbaru, Kalimantan Selatan. Bahan baku yang digunakan dipreparasi terlebih dahulu sebelum menjadi karbon aktif dan dijadikan adsorben. Karbon aktif yang sudah siap digunakan akan diuji karakteristik menggunakan uji kadar air, uji kadar abu, uji daya serap iodium. Karakteristik karbon aktif dilakukan dengan proses preparasi menggunakan $\mathrm{Gas}_{2}$ diinjeksi dengan tekanan 10 bar. Bahan yang telah dipreparasi kemudian dikarbonasi agar memiliki kandungan karbon yang tinggi. Proses karbonasi dilakukan pada suhu $400^{\circ} \mathrm{C}$ selama 4 jam didalam furnace dengan arang tetap berada didalam alat karbonasi. Arang yang sudah dikarbonasi kemudian dikeluarkan dari alat karbonasi dan diayak sehingga berukuran 80-100 mesh sebelum dilakukan proses aktivasi fisika. Proses aktivasi 
fisika dilakukan pada suhu $650^{\circ} \mathrm{C}$ selama $1 \mathrm{jam}$. Karbon yang sudah menjadi karbon aktif kemudian di karakteristik dengan menghitung daya serap iodin terhadap karbon aktif, kadar air, dan kadar abu karbon aktif. Karakteristik karbon aktif limbah kayu ulin dapat dilihat pada Tabel 1.

Tabel 1. Karakteristik Karbon Aktif Limbah Kayu Ulin

\begin{tabular}{clcc}
\hline No & Karakteristik & Jumlah Terkandung & Satuan \\
\hline 1 & Daya serap iodin & 190,350 & $\mathrm{mg} / \mathrm{g}$ \\
2 & Kadar air & 5 & $\%$ \\
3 & Kadar abu & 89 & $\%$ \\
\hline
\end{tabular}

Tabel 1 menunjukkan karakteristik karbon aktif dengan beberapa pengujian dengan prosedur penetapan berdasarkan SNI 06-3730-1995. Standar kualitas karbon aktif yaitu kadar air maksimal untuk serbuk maksimal 15\%, kadar abu maksimal 10\% dan daya serap terhadap iodium minimal 750xmg/g. Kadar air setelah diberi tekanan 10 bar dan aktivasi didapatkan sebesar 5\%. Berdasarkan hasil penelitian menunjukkan bahwa kadar air karbon aktif sudah memenuhi syarat berdasarkan SNI 06-3730-1995. Tujuan dari perhitungan kadar air untuk mengetahui sifat afinitas yang besar terhadap air. Pori - pori karbon aktif akan semakin terbuka karena semakin lama waktu pirolisis, sehingga saat pemindahan karbon aktif dari oven ke desikator dan alat penimbangan terjadi kontak langsung antara karbon aktif yang bersifat higroskopis dengan udara sehingga karbon aktif banyak menyerap uap air (Hartanto dan Ratnawati, 2010). Kadar air disebabkan oleh sifat higroskopis arang dan jumlah uap air pada udara, penggilingan, pengayakan dan penetralan yang terkandung oleh karbon aktif (Husin dan Asmiah, 2020).

Kadar abu yang sudah diberi tekanan 10 bar dan diaktivasi didapatkan sebesar $89 \%$. Kadar abu merupakan banyaknya kandungan oksida logam yang terdiri dari mieral-mineral dalam suatu bahan yang tidak dapat menguap pada proses pengabuan. Kandungan abu dalam karbon aktif dapat mempengaruhi kualitas karbon aktif. Semakin lama proses karbonasi, maka kadar abu yang yang dihasilkan juga semakin meningkat (Kurniawan dkk., 2020). Berdasarkan dari hasil penelitian kualitas karbon aktif yang dihasilkan belum memenuhi standar baku muku karbon aktif karena kadar abu lebih dari 10\% sesuai persyaratan menurut SNI 06-3703-1995.

Daya serap iodium oleh karbon aktif setelah diberi tekanan 10 bar dan diaktivasi sebesar 184,005 $\mathrm{mg} / \mathrm{g}$. Korelasi antara daya adsorpsi karbon aktif terhadap iodin dengan luas permukaan karbon aktif, yaitu semakin besar angka iodin yang diserap berarti semakin besar juga kemampuan karbon aktif dalam mengadsorpsi adsorbat. Sifat reaktif dari karbon aktif dapat dilihat dari kemampuannya mengadsorpsi substrat. Daya adsorpsi karbon aktif dapat ditunjukkan melalui besaran angka iod yaitu angka yang menunjukkan seberapa besar adsorben dapat mengadsorpsi iod (Ikawati dan Melati, 2009). Tinggi rendahnya bilangan iodin juga dapat disebabkan oleh ketidakjenuhan kompnen penyusun karbon aktif (Husin dan Asmlah, 2020). Berdasarkan hasil penelitian, daya serap iodin masih belum memenuhi syarat SNI 06-3703-1995 hal itu bisa saja terjadi karena pengaruh temperatur aktivasi dan waktu karbonasi. Bahan dasar karbon aktif memiliki presentase burn off sangat tinggi. Kondisi ini sebagaian besar bahan dasar hangus terbakar, karena kandungan yang terdapat dari bahan dasar berpengaruh terhadap temperatur aktivasi.

\subsection{Karakterisitk Awal Air Sungai}

Air yang digunakan untuk proses adsorpsi merupakai air sungai yang berasal dari Sungai Martapura, Jalan Gubernur Sarkawi Km. 5,7 Desa Sungai Pinang Lama Kecamatan Sungai Tabuk, Kabupaten Banjar. Air sungai dilakukan karakterisasi terlebih dahulu sebelum diaplikasikan 
pada penelitian ini. Karakterisasi air sungai yang dilakukan yaitu kandungan $\mathrm{COD}$, pH, temperatur, TDS, dan konduktivitas. Hasil dari karakteristik air sungai tersebut dapat dilihat pada Tabel 2.

Tabel 2. Hasil Pengujian Awal Kualitas Air Sungai

\begin{tabular}{clcc}
\hline No & Karakteristik & Jumlah Terkandung & Satuan \\
\hline 1 & COD & 69,45 & $\mathrm{mg} / \mathrm{L}$ \\
2 & pH & 7 & - \\
3 & Temperatur & 29,4 & $\mathrm{oC}$ \\
4 & TDS & 83,5 & $\mathrm{mg} / \mathrm{L}$ \\
5 & Konduktivitas & 180 & $\mu \mathrm{s} / \mathrm{cm}$ \\
\hline
\end{tabular}

Tabel 2. menunjukkan bahwa kandungan COD yaitu 69,45 mg/L yang berarti melebihi baku mutu berdasarkan Peraturan Gubernur Kalimantan Selatan Nomor 5 Tahun 2007 peruntukan air kelas I yaitu $10 \mathrm{mg} / \mathrm{L}$ dan peruntukan kelas II yaitu $25 \mathrm{mg} / \mathrm{L}$. Parameter $\mathrm{pH}$ pada pengujian awal kualitas air sungai yaitu 7, berdasarkan Peraturan Gubernur Kalimantan Selatan Nomor 5 Tahun 2007 $\mathrm{pH}$ air sungai tersebut sudah memenuhi baku mutu yaitu $\mathrm{pH}$ berada pada rentang 6-9. Pengukuran $\mathrm{pH}$ pada perairan merupakan salah satu parameter kimia yang menunjukkan kestabilan parairan (Hamuna dkk., 2018). Kondisi perairan yang terlulau basa ataupun asam akan berdampak terhadap kelangsungan hidup organisme dan mengganggu proses metabolisme serta respirasi organisme perairan.

Hasil uji awal parameter temperatur yaitu $29,4^{\circ} \mathrm{C}$, berdasarkan Peraturan Gubernur Kalimantan selatan No.5 tahun 2007 maka diketahui telah memenuhi baku mutu. Nilai temperatur an didapatkan telah memenuhi standar baku mutu yang ditetapkan, yaitu temperatur udara maksimum yang diperbolehkan adalah $\pm 3^{\circ} \mathrm{C}$ dari temperatur lingkungan. Adapun maksud dari $\pm 3^{\circ} \mathrm{C}$ adalah suhu air sampel harus lebih besar dari $\pm 3^{\circ} \mathrm{C}$ dibandingankan lingkungannya.

Hasil uji awal parameter Total Disolved Solid (TDS) yaitu 83,5 mg/L. Hal ini telah sesuai dengan Peraturan Gubernur Kalimantan selatan No.5 tahun 2007 yan menyebutkan bahwa standar baku mutu air untuk kadar maksimum TDS $1000 \mathrm{xmg} / \mathrm{L}$ untukxair kelas I maupun kelas II. TDS atau padatan terlarut total mengandung material terlarut yang memiliki diameter $<10^{-6} \mathrm{~mm}$, koloid yang berdiameter $10^{-6} \mathrm{~mm}-10^{-3} \mathrm{~mm}$, serta material lain yang tidak tersaring pada kertas saring berdiameter $0,45 \mu \mathrm{m}$. Nilai TDS biasanya disebabkan oleh keberadaan bahan organik berupa ionion yang terlarut di perairan.

Hasil uji konduktivitas air sungai yaitu $180 \mu \mathrm{s} / \mathrm{cm}$. Nilai konduktivitas adalah nilai kemampuan air untuk menghantarkan arus listrik (Aritonang dkk., 2014). Berdasarkan tujuan dari penelitian ini, pengaplikasian karbon aktif kayu ulin pada air sungai ditujukan untuk menurunkan kandungan COD yang ada pada air sungai tersebut.

\subsection{Penentuan Kondisi Optimum Proses Adsoprsi}

Kondisi optimum dalam penelitian ini didapat berdasarkan pada $\mathrm{pH}$ terbaik, waktu kontak setimbang, dan dosis terbaik, waktu kontak setimbang, dan dosis terbaik ditentukan berdasarkan tingkat penyisihan bahan organik tertinggi dalam proses adsorpsi. Grafik tingkat penyisihan untuk penentuan kondisi operasi optimum dapat dilihat pada Gambar 1, Gambar 2 dan Gambar 3. 


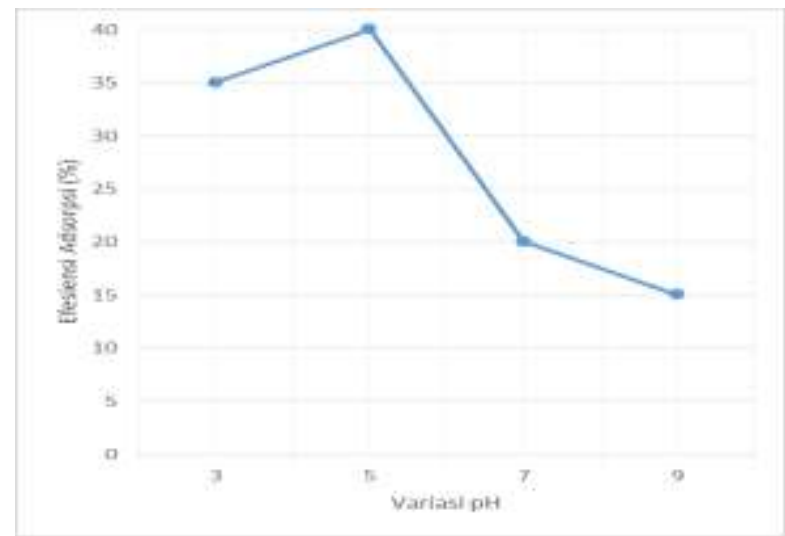

Gambar 1. Tingkat Penyisihan COD dengan Variasi $\mathrm{pH}$

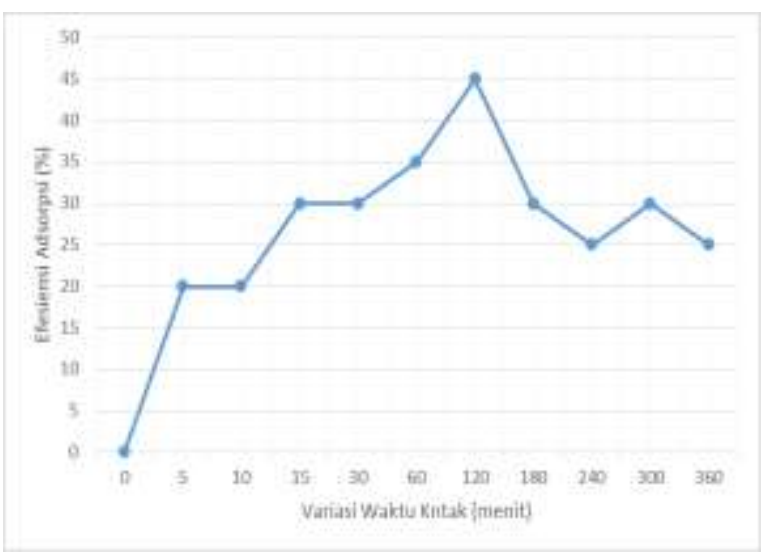

Gambar 2. Tingkat Penyisihan COD dengan Variasi Waktu Kontak

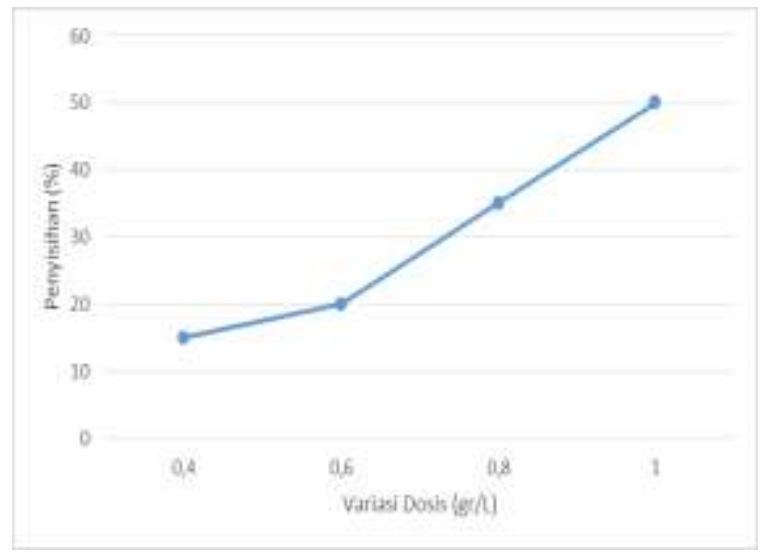

Gambar 3. Tingkat Penyisihan COD dengan Variasi Dosis

Gambar 1. menunjukkan data tingkat penyisihan COD dengan variasi $\mathrm{pH}, \mathrm{pH}$ terbaik berbeda pada pH 5 dengan tingkat penyisihan sebesar 40\%. Pada Gambar 2. dapat dilihat tingkat penyisihan COD dengan variasi waktu kontak, waktu kontak setimbang berada pada waktu 120 menit dengan tingkat penyisihan sebesar 45\%. Tingkat penyisihan COD dengan variasi dosis seperti yang dapat dilihat pada Gambar 3. Data tersebut menunjukkan bahwa dosis terbaik pada penelitian ini yaitu 1 $\mathrm{g} / \mathrm{L}$ dengan tingkat penyisihan sebesar $50 \%$. Kondisi operasi optimum proses adsorpsi COD dalam 
air sungai terdapat pada pH 5, waktu kontak setimbang 120 menit, dan dosis $1 \mathrm{~g} / \mathrm{L}$. Kondisi ini dijadikan dasar dalam menentukan model isoterm dan kinetika adsoprsi pada penelitian ini.

\subsection{Model Isoterm Adsorpsi}

Tujuan dilakukan pemodelan isoterm adsorpsi, yaitu untuk mengetahui hubungan antara jumlah COD yang diadsorpsi arak aktif kayu ulin terhadap variasi konsentrasi pada temperatur kamar. Variasi konsentrasi yang digunakan pada penelitian adalah 20:80, 40:60, 50:50, 60:40, 80:20, dan 100 mg/L. Semakin tinggi konsentrasi maka jumlah ion logam yangxdiadsorpsi semakin tinggi (Sajaya dan Riczy, 2015). Penentuan kapasitas adsorpsi menggunakan beberapa model isoterm adsorpsi, dengan membuat plot linier pada model-model tersebut. Sehingga dapat diketahui nilai koefisien determinasi $\left(\mathrm{R}^{2}\right)$. Nilai koefisien determinasi yang paling mendekati angka satu merupaka model yang cocok untuk menggambarkan proses adsorpsi COD pada karbon aktif kayu ulin dan dengan membandingkan nilai koefisien model yang terbesar. Nilai-nilai parameter untuk isoterm adsorpsi COD terhadap karbon aktif kayu ulin dapat dilihat pada Tabel 3.

Tabel 3. Nilai Parameter Untuk Isoterm Adsorpsi COD Terhadap Karbon Aktif Kayu Ulin

\begin{tabular}{|c|c|c|c|c|}
\hline No. & $\begin{array}{c}\text { Model } \\
\text { Kinetika }\end{array}$ & Parameter & Nilai & Persamaan \\
\hline \multirow{3}{*}{1} & & qmaks & 0,028 & \multirow{3}{*}{$q_{e}=\frac{0,028 \times 43,236 \times C_{e}}{1+43,236 \times C_{e}}$} \\
\hline & Langmuir & KL & 43,236 & \\
\hline & & $\mathrm{R}^{2}$ & 0,9320 & \\
\hline \multirow{3}{*}{2} & & KF & 0,60 & \multirow{3}{*}{$q_{e}=0,60 \times C_{e}{ }^{1 / 2,6560}$} \\
\hline & Freundlich & $\mathrm{n}$ & 2,6560 & \\
\hline & & $\mathrm{R}^{2}$ & 0,8898 & \\
\hline \multirow{4}{*}{3} & \multirow{4}{*}{$\begin{array}{l}\text { Redlich- } \\
\text { Peterson }\end{array}$} & K1 & 170 & \multirow{4}{*}{$q_{e}=\frac{170 \times C_{e}}{1+2847 \times C e^{0,625}}$} \\
\hline & & B & 0,625 & \\
\hline & & $\mathrm{K} 2$ & 2847 & \\
\hline & & $\mathrm{R}^{2}$ & 0,957 & \\
\hline \multirow{3}{*}{4} & & KT & 3,578 & \multirow{3}{*}{$q_{e}=0,0173 \ln \left(3,578 C_{e}\right)$} \\
\hline & Temkin & $\mathrm{B}$ & 4,214 & \\
\hline & & $\mathrm{R}^{2}$ & 0,8559 & \\
\hline
\end{tabular}

Tabel 3. menunjukkan nilai koefisien determinasi $\mathrm{R}^{2}$ untuk model isoterm Langmuir, Freundlich, Redlich-Peterson dan Temkin berturut-turut yaitu 0,9320, 0,8898, 0,957 dan 0,8559. Pada hasil ini diperoleh model isoterm Langmuir dan Redlich-Peterson memiliki korelasi yang sangat baik. Hal ini terlihat dari nilai koefisien determinasi yang tinggi, yaitu $\mathrm{R}^{2} \geq 0,9$ (mendekati angka 1). 
Berdasarkan tingginya koefisien determinasi dari keempat model tersebut, maka dapat dikatakan bahwa kesetimbangan adsorpsi COD oleh karbon aktif kayu ulin menunjukkan kesesuaian yang lebih oleh model isoterm Redlich-Peterson. Menurut hasrianti (2012) spesies yang berbeda memberikan karakteristik penyerapan yang berbeda. Oleh karena itu, kesesuaian dari isotermal adsorpsi bergantung pada spesies adsoerben yang digunakan. Isoterm model isoterm Langmuir mengasumsikan bahwa permukaan adsorben adalah homogen dan besarnya energi adsorpsi ekuivalen untuk setiap situs adsorpsi. Model ini mendefinisikan bahwa kapasitas adsorpsi maksimum terjadi akibat adanya lapisan tunggal (monolayer) adsorbat dipermukaan adsorben. Menurut Muna (2011) menyatakan bahwa Adsorpsi secara kimia terjadi karena adanya interaksi antara situs aktif adsorben dengan zat teradsorpsi dan interaksi hanya terjadi pada lapisan penyerapan tunggal (monolayer adsorption) permukaan dinding sel adsorben. Hasil simulasi model isoterm adsorpsi dapat dilihat pada Gambar 4.

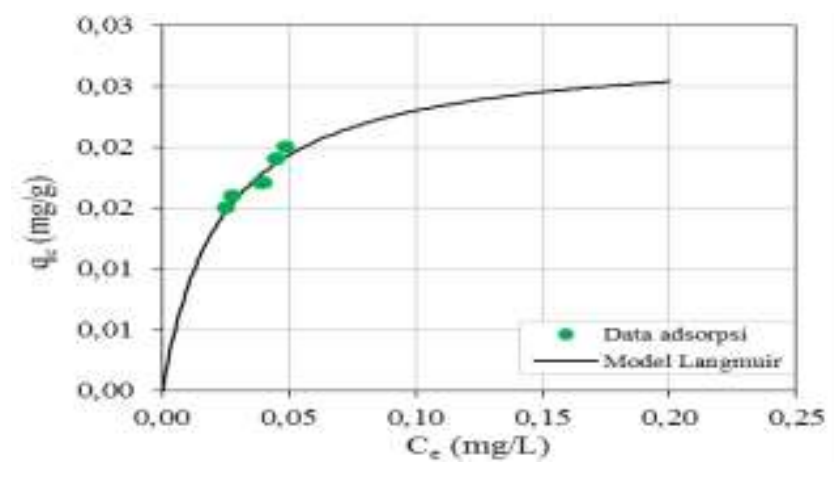

Gambar 4. Simulasi Model Langmuir

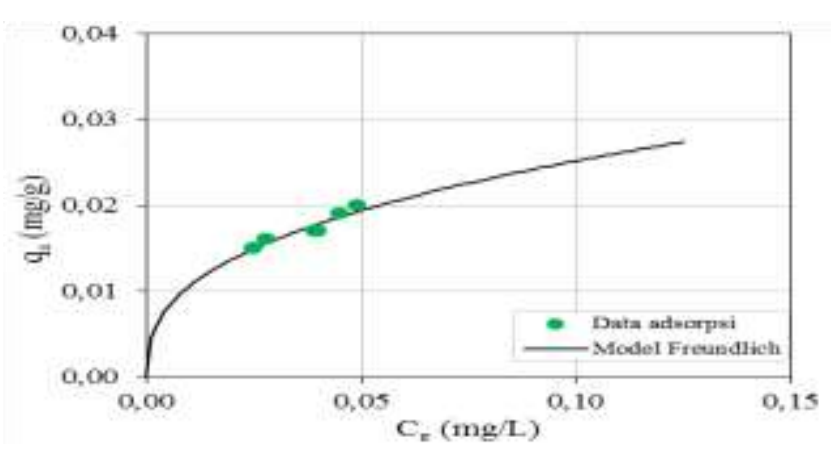

Gambar 5. Simulasi Model Freundlich 


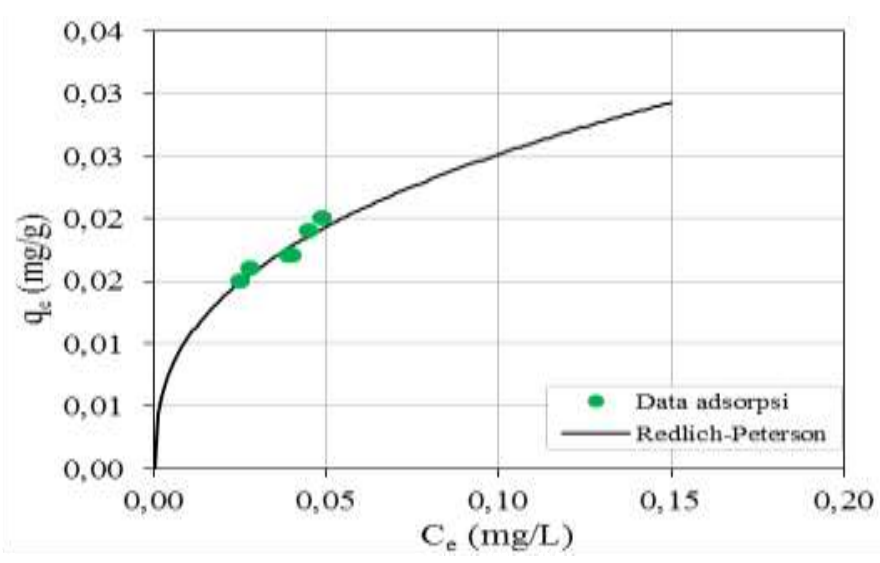

Gambar 6. Simulasi Model Redlich-Peterson

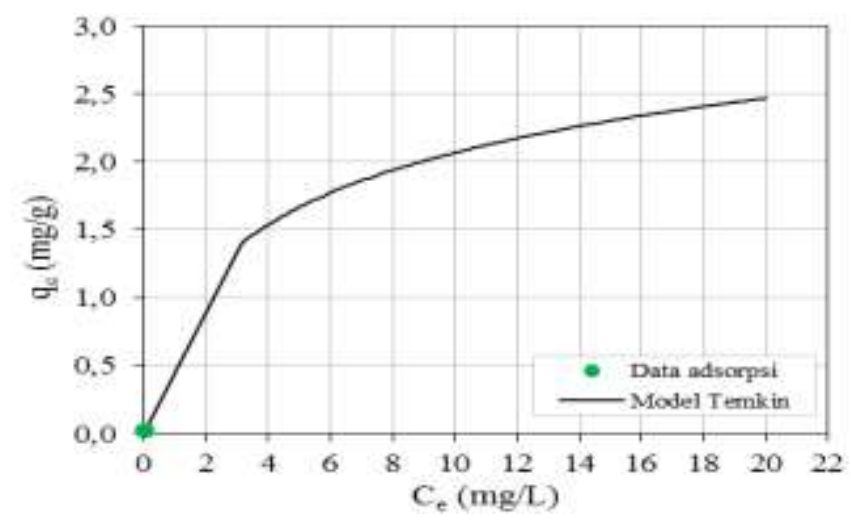

Gambar 7. Simulasi Model Temkin

\subsection{Model Kinetika Adsoprsi}

Pemodelan kinetika adsorpsi merupakan penggambaran laju reaksi pengikatan zat terlarut pada perubahan waktu kontak. Penggunaan model kinetika reaksi dapat ditujukan untuk pengolahan data penanganan limbah cair pada proses adsorpsi serta penentuan variabel terkait dalam adsorpsi dan mekanisme adsorpsi yang terjadi. Ukuran laju adsorpsi berdasarkan pada lama waktu kontak untuk mencapai kesetimbangan.

Waktu kontak merupakan faktor penting dalam proses adsorpsi. Semakin lama waktu kontak antara adsorben dan adsorbat, maka jumlah adsorbat yan terserap semakin banyak hingga adsorben mencapai titik jenuh yang berakibat pada terhentinya proses adsorpsi (Judy, 2015). Faktor yang memepengaruhi jumlah waktu yang diperlukan untuk mencapai keadaan setimbang adalah kemampuan adsorben dalam mengadsorpsi polutan.

Selama terjadi kontak antara partikel adsorbat dan adsorben akan terjadi proses dua arah yaitu adsorpsi dan desorpsi. Pada saat mencapai titik kesetimbangan, laju adsorpsi akan menyamai laju desoprsi sehingga konsentrasi adsorbat dalam pelarutannya tetap. Waktu yang diperlukan dari mulai terjadi kontak adsorbat dengan adsorben sampai terjadi kesetimbangan, dianggap bahwa semua bagian pada permukaan adsorben telah terisi oleh partikel adsorbat (Maulida, 2016). Pengaruh waktu kontak terhadap kapasitas adsorpsi dapat dilihat pada Gambar 8. 


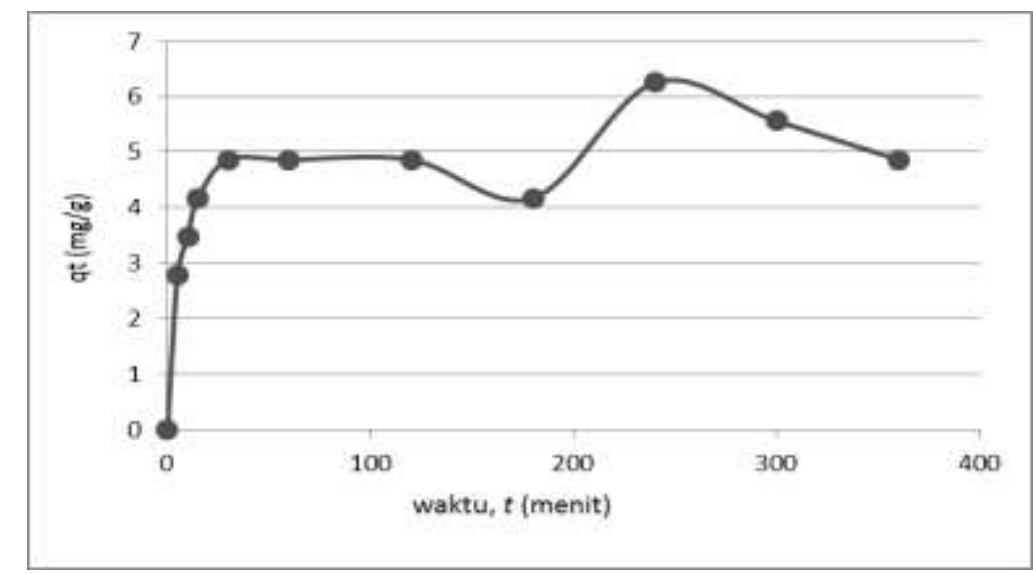

Gambar 8. Pengaruh waktu kontak terhadap kapasitas adsorpsi

Gambar 8 menunjukkann bahwa adsorpsi COD oleh karbon aktif kayu ulin semakin besar seiring dengan lama waktu kontak yang bertambah dan adsrorpsi COD mencapai kondisi ekuiliburn pada waktu 240 menit. Penyebab hal ini terjadi karena semakin lama waktu interaksi adsorben dengan adsorbat kemungkinan terjadi tumbukan akan semakin banyak sehingga semakin banyak adsorbat yang terserap pada permukaan adsorben. Namun, pada waktu kontak pada 5 menit sampai dengan 30 menit menunjukkan bahwa pada waktu tersebut proses adsorpsi COD oleh karbon aktif belum maksimal, sehingga pada waktu kontak tersebut terlepasnya ion $\mathrm{H}^{+}$pada karbon aktif (Muna, 2011).

Setelah interaksi berlangsung 240 menit adsorpsi COD oleh karbon aktif kayu ulin menjadi kondisi konstan. Hal ini berarti keadaan setimbang telah tercapai. Penentuan waktu kesetimbangan ditujukan untuk mengetahui titik waktu adsorben mengalami kejenuhan dan proses adsorpsi terhenti (Muna, 2011). Penelitian ini menunjukkan bahwa pada waktu kontak 240 menit kapasitas adsorpsi permukaan karbon aktif telah jenuh dan telah tercapai kesetimbangan sehingga penyerapan pada menjadi konstan atau hampir sama. Menurut Rahmawati (2012) menyatakan bahwa apabila proses adsorpsi telah mencapai kesetimbangannya, maka tambahan waktu kontak tidak dapat meningkatkan jumlah logam teradsorpsi.

Data kinetika adsorpsi yang didapatkan pada penelitian ini dilakukan secara batch dan dievaluasi menggunakan tiga model makanistik, yaitu model pseudo orde satu, model pseudo-orde dua, dan model Freundlich modifikasi. Ketiga model tersebut telah diaplikasikan secara luas untuk menentukan pemodelan dalam bidang adsorpsi sistem liquid-solid. Model kinetika yang sesuai untuk sistem COD pada karbon aktif kayu ulin dilakukan dengan membandingkan nilai koefisien determinasi $\left(\mathrm{R}^{2}\right)$. Nilai koefisien determinasi yang paling mendekati nilai satu merupakan model yang sesuai atau tepat untuk menggambarkan proses adsorpsi COD oleh karbon aktif kayu ulin. Berikut ini beberapa model kinetika adsorpsi COD pada karbon aktif kayu ulin ditunjukkan pada Gambar 9. sampai Gambar 11. 


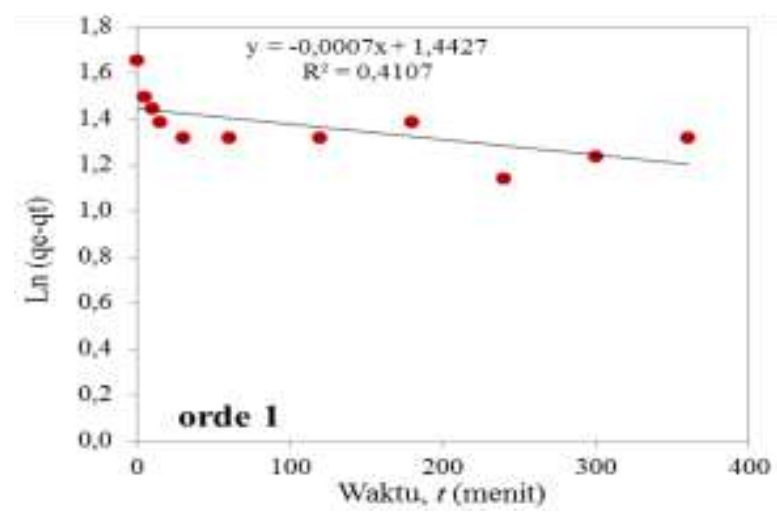

Gambar 9. Plot Linier Mode Pseudo Orde Satu

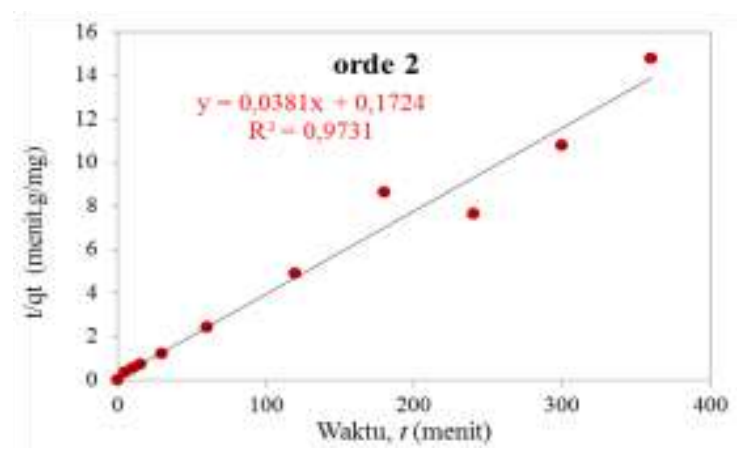

Gambar 10. Plot Linier Mode Pseudo Orde Dua

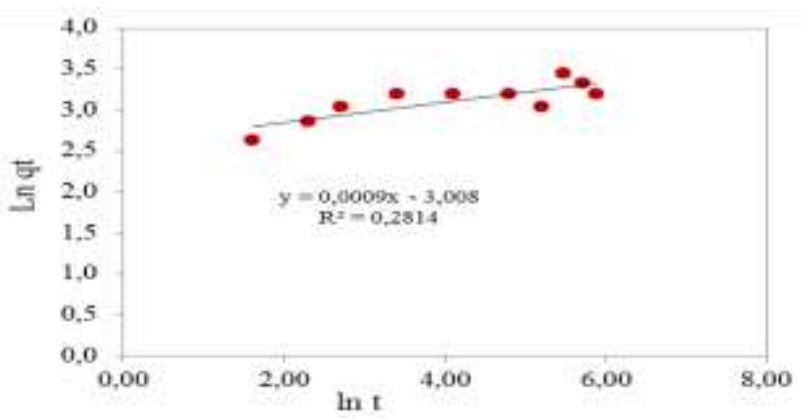

Gambar 11. Plot Linier Model Freundlich Modifikasi

Penentuan model kinetika yang sesuai dari model pseudo orde satu, model pseudo orde dua dan Freundlich modifikasi dilakukan dengan regresi linier. Model kinetika adsorpsi COD terhadap karbon aktif kayu ulin diuraikan pada Tabel 4. 
Tabel 4. Model Kinetika untuk Adsorpsi COD Karbon Aktif Kayu Ulin

\begin{tabular}{|c|c|c|c|c|}
\hline No & $\begin{array}{c}\text { Model } \\
\text { Kinetika }\end{array}$ & Parameter & Nilai & Persamaan \\
\hline \multirow{4}{*}{1} & \multirow{4}{*}{$\begin{array}{l}\text { Pseudo } \\
\text { Orde } 1\end{array}$} & qe percobaan & 45 & \\
\hline & & qe model & 13,899 & \\
\hline & & K1 & 0,0016 & $q_{t}=q_{e} \times\left(1-\frac{1}{\left.10^{0,0016 \times C e / 2,303}\right)}\right)$ \\
\hline & & $\mathrm{R}^{2}$ & 0,4107 & $q_{t}=\frac{t}{\left(\frac{1}{\left(0,25^{2}\right.}\right)+(t / 26,24)}$ \\
\hline \multirow{4}{*}{2} & \multirow{4}{*}{$\begin{array}{l}\text { Pseudo } \\
\text { Orde } 2\end{array}$} & qe percobaan & 45 & \\
\hline & & qe model & 26,24 & \\
\hline & & $\mathrm{K} 2$ & 0,0084 & \\
\hline & & $\mathrm{R}^{2}$ & 0,9731 & \\
\hline \multirow{4}{*}{3} & \multirow{4}{*}{$\begin{array}{l}\text { Freundlich } \\
\text { Modifikasi }\end{array}$} & qe percobaan & 26,25 & \multirow{4}{*}{$q_{t}=0,193 \times 69,45 \times($ Ce $\times 0,0009)$} \\
\hline & & K & 0,193 & \\
\hline & & Slope & 0,0009 & \\
\hline & & $\mathrm{R}^{2}$ & 0,2814 & \\
\hline
\end{tabular}

Dari Gambar 9 sampai Gambar 11 dan pada Tabel 4 dilihat bahwa persamaan garis yang didapatkan dari line arisasi adalah $\mathrm{y}=-0,0007 \mathrm{x}+1,4427$ dengan $\mathrm{R} 2=0,4107$ untuk model pseudo orde satu (Gambar 9), model pseudo orde dua persamaan garis yang didapatkan dari linearisasi adalah $\mathrm{y}=0,0381 \mathrm{x}-0,1724$ dengan $\mathrm{R}^{2}=0,9731$ (Gambar 10), dan untuk Freundlich modifikasi (Gambar 11) persamaan garis linearisasinya adalah $y=0,0009 x+3,008$ dengan $R^{2}=0,2814$. Dari ketiga model tersebut dilihat dari nilai koefisien determinasi menunjukkan perbedaan yang cukup signifikan. Koefisien determinasi pada model pseudo orde satu dan model Freundlinch modifikasi menunjukkan nilai yang cukup rendah dibandingkan dengan koefisien determinasi model pseudo orde dua. Sehingga dapat dikatakan bahwa kinetika adsorpsi COD pada karbon aktif kayu ulin merupakan model kinetika pseudo orde dua. Nilai konstanta laju adsorpsi (K2) yang tertinggi menunjukkan bahwa kekuatan pendorong untuk adsorpsi COD terhadap karbon aktif kayu ulin. Berikut dapat dilihat kecocokan model pseudo orde dua pada Gambar 12. 


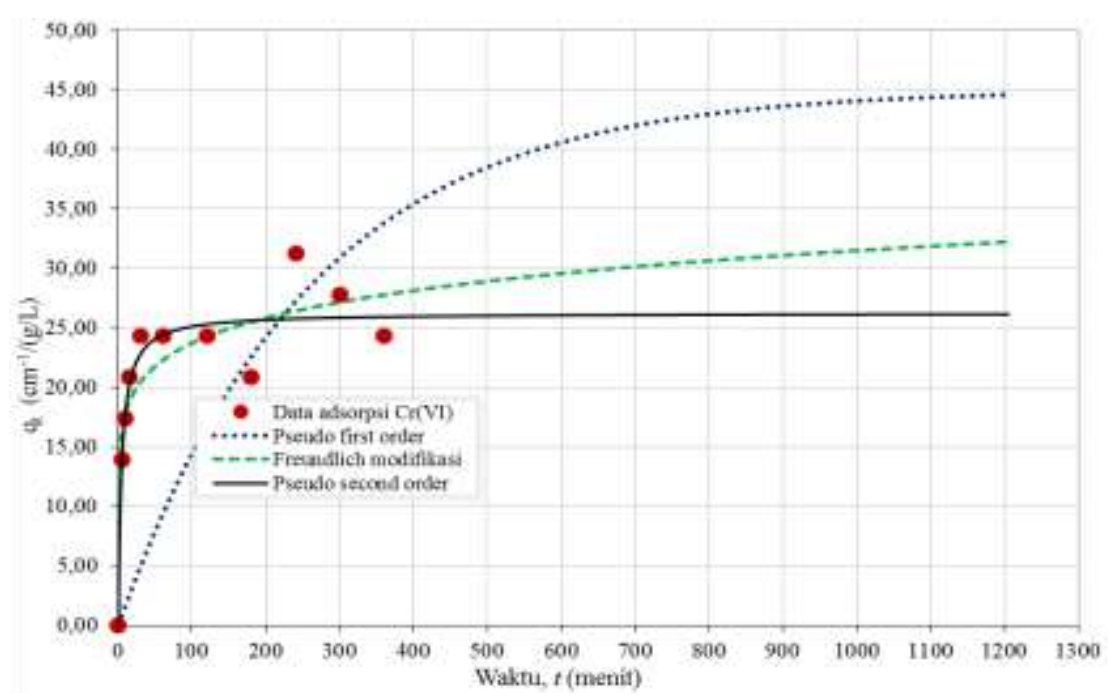

Gambar 12. Model Kinetika Adsorpsi COD Karbon aktif kayu ulin

Gambar 12 menggambarkan model kinetika pada proses adsorpsi COD terhadap karbon aktif serbuk kayu ulin dengan model yang paling sesuai adalah model pseudo orde dua. Judy (2015) menyatakan bahwa model pseudo orde dua merupakan persamaan laju reaksi yang dipengaruhi oleh adsorpsi kimia yang melibatkan ikatan valensi melalui pertukaran elektron antara adsorben dan adsorbat. Model kinteik berupa pseudo orde dua menunjukkan proses adsorpsi menyisihkan adsorbat kecil dan berlangsung lambat. Hal ini berarti kemungkinan laju adsorpsinya dikontrol oleh mekaniseme adsorpsi secara kimia (Mahmud dan Maulida, 2016).

\subsection{Mekanisme Adsorpsi}

Hasil analisis model isoterm dan kinetika yang dilakukan pada penelitian ini diperoleh model isoterm Redlich-Peterson dan model kinetika Pseudo orde dua. Model isoterm Redlich-Peterson merupakan gabungan elemen-elemen dari kedua persamaan Langmuir dan Freundlich serta mekanisme adsorpsinya merupakan penggabungan dari kedua isoterm tersebut. Pada model kinetika diperoleh model Pseudo orde dua yang memiliki kecenderungan terjadinya proses secara kimia. Jika nilai R2 pada pseudo orde satu lebih besar dan mendekati angka 1 dari pada nilai R2 Pseudo orde dua maka dapat dikatakan adsoprsi yang berjalan melibatkan reaksi fisika. Sebaliknya jika nilai R2 pada Pseudo orde dua lebih besar dan mendekati angka 1 dari pada Pseudo orde satu maka dapat diasumsikan bahwa adsorpsi melibatkan reaksi kimia. Berdasarkan hasil analisis isoterm diketahui bahwa proses yang adsorpsi COD pada air sungai terhadap karbon aktif kayu ulin terjadi secara kimia sedangkan hasil analisis kinetika lebih menunjukkan bahwa terjadi proses secara kimia. Model isoterm yang paling sesuai untuk menggambarkan proses adsorpsi COD ai sungai terhadap karbon aktif kayu ulin dari keempat model isoterm yakni model isoterm Redlich-Peterson. 


\section{KESIMPULAN}

Simpulan dari penelitian ini sebagai berikut.

1. Model Isoterm yang tepat untuk menggambarkan proses adsorpsi COD terhadap karbon aktif kayu ulin secara berurutan adalah model Isoterm model Langmuir, Redlich-Peterson, Freundlich dan Temkin dengan nilai $\mathrm{R}^{2}$ adalah 0,9320; 0,8898; 0,957 dan 0,8559.

2. Model kinetika yang tepat menggambarkan proses adsorpsi COD air sungai terhadap karbon aktif kayu ulin adalah model kinetika Pseudo orde dua.

3. Berdasarkan hasil dari model isoterm dan kinetika mekanisme adsorpsi COD air sungai terjadi secara fisika dan kimia dengan didominasi oleh mekanisme secara kimia.

\section{DAFTAR PUSTAKA}

Badariah,x(2013). IsolasixAlkaloid Bersifat Antimakan Pada Kayu Bulian (Eusideroxylonzwage ri $T$ et $B$ ). IAIN STS Jambi. FMIPA Universitas Lampung.

Hasrianti. (2012). Adsorpsi Ion $\mathrm{Cd}^{2+}$ dan $\mathrm{Cr}^{6+}$ Pada Limbah Cair Menggunakan Kulit Singkong. Universitas Hasanuddin. Makassar.

Indis, N.A., dan Ulfin, I. (2013). AdsorpsixIon Cr (VI) Menggunakan Karbon Aktif yang Terbuat dari Tempurung Biji Nyamplung. FMIPA, Institut Teknologi Sepuluh Nopember (ITS). Surabaya.

Matilda, F., Biyatmoko, D., Rizali, A., dan Abdullah. (2016). Peningkatan Kualitas Efluen L imbah Cair Industri Tahu Pada Sistem Lumpur Aktif Dengan Variasi Laju Alir Mengg unakan Arang Aktif Kayu Ulin (Eusideroxylon zwageri). EnviroScienteae, 12(3): 207215.

Maulida, W. (2016). Studi Isoterm dan Kinetika Adsorpsi Krom Heksavaken $\left(\mathrm{Cr}^{6+}\right)$ xterhadap AdsorbenxGambutxdenganxSistemxBatch. Laporan Penelitian. Fakultas Teknik Universita s Lambung Mangkurat Banjarbaru.

Peraturan Menteri. (2008). Peraturan Menteri Lingkungan Hidup Nomor 15 Tahun 2008.

Sirajudin, M. Syahrir, dan I. Syahrir. (2017). Optimasi Kecepatan Pengadukan Pada Proses Adsorpsi Limbah Cair Laundry untuk Menurunkan Kadar Surfaktan Menggunakan BatuBara. Makalah disajikan dalam Seminar Nasional Sains dan Teknologi Fakultas Teknik Universitas Muhammadiyah Jakarta. Jakarta.

Suharja, I., dan Jumani, J. (2017). Riap Tanaman Ulin (Eusidero ylonxzwageri Teijsm \& Binn) di KHDTK Samboja Kecamatan Samboja Kabupaten Kutai Kartanegara Provinsi Kalim antan Timur. Jurnal AGRIFOR, 16(1): 49-58.

Syafalni, S., Abustan, I., Dahlan, I., Wah, C.K., dan Umar, G. (2012). Treatment of Dye Wastewater Using Granular Activated Carbon and Zeolite Filter. Modern Applied Scien ce, 6(2): 37-51. 